\title{
PASANGAN LEGENDARIS ITU BERNAMA GUS CICI
}

\author{
Oleh: M. Jamil ${ }^{1}$
}

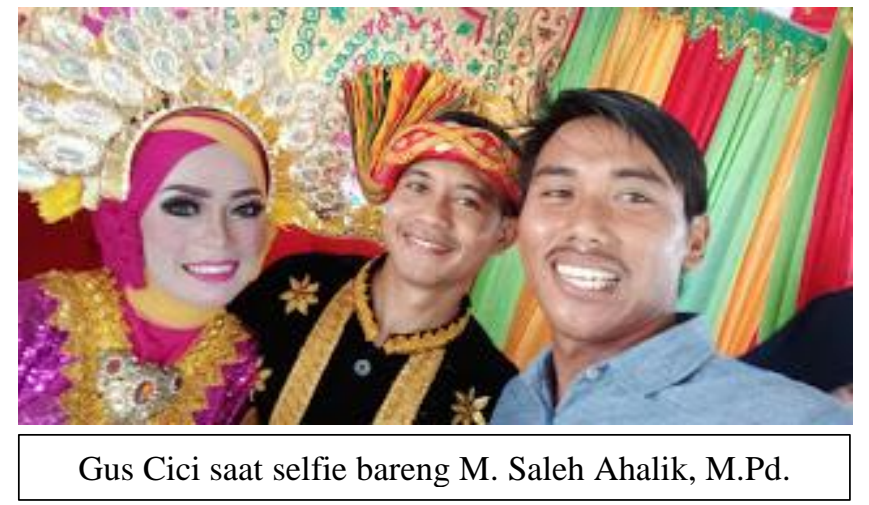

PEWARTA-news.com

Malam ini nikmat terasa, karena bisa makan makanan khas Bima bikinan salahsatu adek. Makanan tersebut disantap rame-rame 4 orang (saya, Abi Soepomo, Rizal, Lepas), gus Coy pasti rindu momen makan bareng seperti ini. Namun Gus Coy saat-saat ini bisa dengan mudah dia dapatkan bila berkeinginan makan makanan khas Bima, karena saat ini Gus Coy sedang berada di kampung halaman (Bima). Gus Coy, selamat menikmati dengan leluasa keindahan suasana Bima beserta masakan-masakan khasnya.

Entah mengapa, usai makan makanan khas Bima ini tiba-tiba ingat kak Agustina dan Bang Cici (Agustinasari dan Rizalul Fiqry --khusus dalam tulisan ini Penulis singkat dengan Gus Cici), sepasang kekasih legendaris yang siang tadi (Ahad, 16 Desember 2018) di Paruga Na'e, Desa Talabiu, Kecamatan Woha, Kabupaten Bima, Provinsi Nusa Tenggara Barat (NTB) telah resmi menjadi sepasang suami istri (mereka melangsungkan resepsi pernikahan terkeren yang akan selalu dikenangnya sepanjang masa).

1 Ketua Umum Pusat Studi Mahasiswa Pascasarjana (PUSMAJA) Mbojo-Yogyakarta Periode 2015-2017 | | Ketua II Bagian Eksternal Dewan Pimpinan Cabang Perhimpunan Mahasiswa Hukum Indonesia Daerah Istimewa Yogyakarta (DPC PERMAHI DIY) Periode 20122014 | Email: jamilncera@gmail.com | FB/Youtube/IG/Twitter: @MJAMILSH | Website: http://www.mjamil.my.id. 


\section{Terbit 17 Desember 2018}

"Pasangan Legendaris itu Bernama Gus Cici"

Mereka berdua merupakan pasangan legendaris dimata teman-teman Keluarga Pelajar Mahasiswa (KEPMA) Bima-Yogyakarta, di mata rekan-rekan Pusat Studi Mahasiswa Pascasarjana (PUSMAJA) Mbojo-Yogyakarta, di mata Mahasiswa Mbojod di Yogyakarta, dan setidak-tidaknya mereka Pasangan Legendaris di mata saya pribadi.

Penulis merasa tidak ecek-ecek menyebut mereka sebagai pasangan legendaris. Setidak-tidaknya, Penulis mengetahui percikan, sahdunya, dan harmonisnya kisah asmara mereka sejak 10 tahun silam (penulis di Jogja akhir 2007), sejak awalawal Penulis menginjakkan kaki di tanah penuh sejuta kenangan, yakni kota Gudeg Yogyakarta, yang juga dikeramatkan sebagai kota Budaya dan Kota Pendidikan ini.

Kisah mereka masa silam, masih teringat dalam memori ingatan Penulis, akan keindahan dan romantisnya kisah sepasang sejoli legendaris ini. Mereka selalu berdua menelusuri romantisnya sudut-sudut kota Jogja dengan penuh riang gembira. Sesekali terkadang penulis melihatnya ketika mereka lewat di jalan depan kampus UNY dengan motor yang terbilang juga legendaris, karena motor itu terlihat sudah termakan usia. Ketika mereka lewat, penulis hanya tersenyum bahagia, karena juga menyaksikan keharmonisan yang terpancar dari mimik wajah mereka. Sebenarnya bisa saja Penulis memanggil dengan meneriaki mereka, namun hati tak sanggup mengusik keasikan mereka. Toh setiap saat juga bisa bertemu mereka. Lalu motor yang dikendarai mereka pun melaju dengan santai ke arah timur, dan mereka pun hari itu berlalu tanpa jejak, karena terhalang tembok-tembok dan juga pepohonan di kejauhan sana (wilayah depan rektor UNY).

Disuatu waktu yang lain juga, yakni di acara-acara KEPMA Bima-Yogyakarta yang saya ikuti berkali-kali juga di masa silam, selalu melihat mereka bedua berjalan beriringan secara harmonis sebagai sepasang kekasih. Begitu juga ketika menghadiri acara-acara pentas yang diselenggarakan Sanggar Seni dan Tradisi 


\section{Terbit 17 Desember 2018}

"Pasangan Legendaris itu Bernama Gus Cici"

RIMPU masa lampau, sepasang sejoli legendaris itu juga selalu dapat Penulis saksikan.

Cinta mereka telah tertancap kokoh dengan pondasi yang amat kuat. Sehingga ketika terhalang dan tergoyah dengan kondisi apa pun tetap utuh dalam keharmonisan cinta mereka. Cinta mereka bukan cinta abal-abal, yang mudah tergoyah tanpa sebab.

Cinta mereka, kalau meminjam iklan semen tiga roda, "Kokoh Tak Tertandingi, sebagai contoh ketika behubungan Long Distance Relationship (LDR) / hubungan jarak jauh beberapa tahun terakhir (kak Agustina di Bima dan bang Cici melanjutkan studi di Jogja), mereka tetap mampu melewatinya, dan terbukti siang tadi, 16 Desember 2018, mereka telah sukses menjadi Cinderella dan sang Pangeran dalam panggung resepsi yang megah.

Sebenarnya tidak mungkin dapat Penulis rajut semua kisah mereka, karena saking begitu banyaknya kisah keindahan cinta mereka. Namun pada intinya yang ingin diungkapkan saat ini adalah, "Selamat Buat Bang Cici dan kak Agustina. Limpahan kebahagiaan semoga selalu mewarnai bahtera indahnya keluarga kalian berdua. Aamiin."

Yogyakarta, 16 Desember 2018

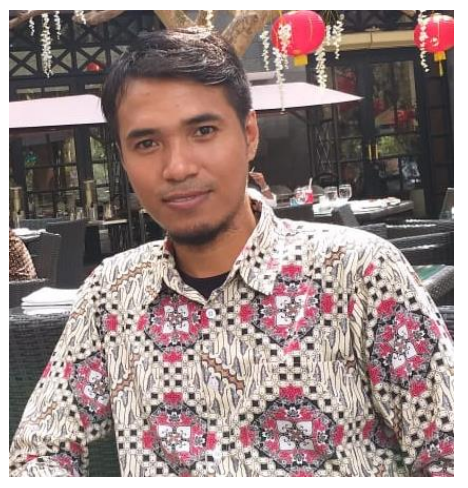

Penulis: M. Jamil, S.H.

Ketua Umum Pusat Studi Mahasiswa Pascasarjana (PUSMAJA) Mbojo-Yogyakarta Periode 2015-2017 | Ketua II Bagian Eksternal Dewan Pimpinan Cabang Perhimpunan Mahasiswa Hukum Indonesia Daerah Istimewa Yogyakarta (DPC PERMAHI DIY) Periode 2012-2014. 
Terbit 17 Desember 2018

"Pasangan Legendaris itu Bernama Gus Cici"

\section{Ful Sumber Tulisan:}

M. Jamil, "Pasangan Legendaris itu Bernama Gus Cici", dimuat di https://www.pewarta-news.com/2018/12/pasangan-legendaris-itu-bernama-guscici.html, pada 17 Desember 2018. 